\title{
The European Court of Justice's Decision Regarding the Brüstle Patent and Its Implications for the Legality of Stem Cell Research Within the European Union
}

Martin Heyer ${ }^{1, *}$ and Tade Matthias Spranger ${ }^{2, * *}$

\section{ABSTRACT}

In 2011 the European Court of Justice issued a decision regarding the patentability of technologies derived from human embryonic stem cells. The finding will have an impact on the framework of stem cell research within the European Union and its Member States and has already triggered several political initiatives regarding the funding of research with human embryonic stem cells on the European level as well as a renewed public debate. This article will take a short look at the case history and the findings of the court. It offers some critical comments regarding the findings' consistency with European and international regulations on intellectual property rights as well as some considerations on the possible impact of the case for other fields of law.

\section{Case history}

In 2004, Greenpeace filed a lawsuit against a patent claim made by the German scientist Oliver Brüstle at the German patent court. The contested claim, ${ }^{1}$ which was filed in 1997, encompassed a patent on isolated and purified neural progenitor cells and was granted by the patent office. The progenitor cells in question were derived from embryonic stem cells

\footnotetext{
${ }^{1}$ Institute of Science and Ethics, Stem Cell Network North Rhine Westphalia, and ${ }^{2}$ Institute of Science and Ethics and Faculty of Law, University of Bonn, Bonn, North Rhine Westphalia, Germany.

*(Correspondence: heyer@iwe.uni-bonn.de)

**(Correspondence: spranger@iwe.uni-bonn.de)

${ }^{1}$ Patent No.: DE 19756864 C1.
}

extracted in Israel. Whereas the establishment of human embryonic stem cell lines in Germany is prohibited by the Embryo Protection Act (EmbryonenschutzgesetzEschG), the import of such stem cells to Germany is, according to the German Stem Cell Act (Stammzellgesetzes - StZG), permissible under certain conditions. During the research project, all legal procedures had been observed; it was thus in accordance with German law.

Nevertheless, Greenpeace claimed the patent to be invalid because the cells used for research had been originally extracted from human embryos. ${ }^{2}$ They argued that

${ }^{2}$ For a more detailed sketch of the case history, also see Molnár-Gábor, Fruzsina, Oliver Brüstle

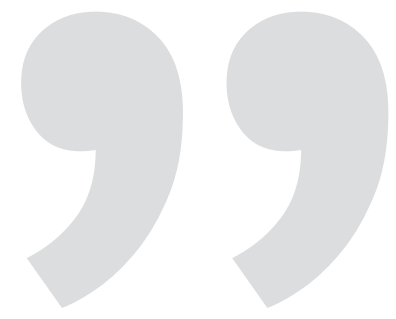

"One question that arises in consequence of the decision is: will the findings of the EUCJ have consequences for other areas than patent law?"

any endeavor using cells that are derived from human embryos, thus necessitating the destruction of a human embryo in the past, constitutes a moral offense. This would exclude patentability. Greenpeace's viewpoint was substantiated by reference to $\S 2$ Section 1 No. 3 of the German Patents Act (Patentgesetz-PatG), which states that the "use of human embryos for industrial or commercial purposes" constitutes a breach of ordre public and thus precludes patentability.

The defendant appealed the motion, stating that his research was in accordance

gegen Greenpeace e.V., Freiburger Informationspapiere zumVölkerrecht und Öffentlichen Recht, S. Vöneky (ed.), Freiburg 6/2012. 
with the rules of the German Stem Cell Act. Legally permissible research could not at the same time be a breach of public policy within the terms of patent law.

In 2006, the German Federal Patents Court (Bundespatentgericht_-BPatG) partially justified the claim made by Greenpeace in a highly controversial verdict by rejecting the defendant's arguments. According to this decision, any scientific research using cells that were originally derived from human embryos that were destroyed in the process - however distant that connection may be - cannot be patented. At this point the court fell in line with the broad interpretation of the term "use of human embryo" that the claimant had brought forward.

Brüstle appealed that verdict at the German Federal Court of Justice (Bundesgerichtshof-BGH). The German Federal Patents Court's decision, he argued, ignored the regulations of the German Stem Cell Act. ${ }^{3}$ After a long and careful consideration, the German legislator decided to enable the development of treatments based on human embryonic stem cells within the framework of the Stem Cell Act. German law not only declares the destruction of human embryos for research purposes (and thus the establishment of human embryonic stem cell lines) a criminal offense, punishable by up to 3 years of imprisonment, but also puts strict limitations on the import of stem cell lines that have been established abroad. Only stem cells that were extracted before the legally determined cut-off date can be imported. This aims to prevent incentives coming from Germany for the destruction of embryos abroad. However, it was exactly these requirements that were not involved in the case at hand, emphasized the defendant. The invention did not necessitate the destruction of human embryos. The research project leading to the claim only used stem cells that had been extracted

${ }^{3}$ Oliver Brüstle repeated that argument in an interview with the Stem Cell Network North Rhine Westphalia (www.stammzellen.nrw.de/file admin/media/documents/presse/Interview KNW_110509-1.pdf). The interview is not available in English. from human embryos before the cut-off date and had been imported in accordance with German law. Thus, the invention did not require any use of human embryos for industrial or commercial purposes.

After a pretrial conference, the BGH concluded that they would be able to make a decision in the case only after certain open legal terms had been clarified by the European Court of Justice (ECJ). The relevant passages of the German Patent Act were literally implemented from the European Directive 98/44 (Biopatent Directive). The sovereignty of interpretation for the critical terms of this case thus rested with the ECJ.

The BGH submitted to the ECJ, inter alia, the following questions ${ }^{4}$ :

- What is the meaning of the term "human embryo" used in Article 6(2)(c) of 98/44/EC? Does it encompass all stages of human development beginning with fertilization?

- What is the meaning of the term "use of human embryos for industrial or commercial purposes" in Article 6(2)(c) of 98/44/EC? Does this also cover scientific research?

- Does Article 6(2)(c) of 98/44/EC also preclude patentability for a technology if the patent claim does not include the destruction of human embryos but if destruction of a human embryo is a necessary condition for the application of said technology?

\section{The ECJ's findings}

In October 2011 the ECJ answered these questions, ${ }^{5}$ with a judgment that was surprisingly explicit according to a large part of the legal community.

Contrary to the mostly uniform way, up until now, of leaving the interpretation of

${ }^{4}$ The decision of the $\mathrm{BGH}$ and the detailed questions are available at http://juris.bundesg erichtshof.de/cgi-bin/rechtsprechung/document .py?Gericht $=$ bgh \&Art $=e n \& n r=50583 \&$ pos $=0 \& a$ $\mathrm{nz}=1$ The decision is not available in English.

${ }^{5}$ The judgment can be found at http://curia .europa.eu/juris/document/document.jsf?text= \& docid $=111402$ \&pagelndex $=0$ \&doclang $=E N \&$ mode $=$ lst $\&$ dir $=\& o c c=$ first $\&$ part $=1 \&$ cid $=4615515$ important legal terms, for which there is no consensus in the legal systems of the member nations, to the values consensus and legal traditions of the member nations themselves, the ECJ defined a uniform and very broad concept of the term "embryo" for the field of patent law. An embryo is, subsequently, each human egg cell from the stage of its fertilization onward. Even unfertilized egg cells, which gain the potential to develop into complete organisms through artificial means (cell nuclear transfer constructs, parthenogenesis, etc.), were included in this definition. Regarding cell types that are extracted from embryos in the blastocyte phase, the ECJ found that it is the business of the national courts to decide, in light of the technical development, whether the cells have the ability to develop to complete organisms and thereby fall within purview of this definition.

Regarding the term "use," the ECJ decided that every invention regarding a process that includes the prior destruction of embryos, or their use as source material, represented an industrial or commercial use of embryos. According to the court, it is immaterial whether the process - such as in the current case-did not refer to the use of human embryos. Finally, the court did also find that using embryos for research purposes is an industrial or commercial use in terms of the biopatent directive and thus leads to the exclusion of patentability.

\section{Some comments on the} ECJ's decision

The ECJ's decision has gained a lot of critical attention in the public as well as in legal discourse. Scientists and politicians were - and still are-worried about the impact this decision may have for the future of stem cell research in Europe. This article refrains from speculating about the economical or scientific effects the court's decision might have. Instead, it will point out some purely legal arguments from various fields of law that put a serious stress on the rationale of the court and, from our point of view, make the decision seem less than convincing. 


\section{The Single European}

\section{Market argument}

The court's basic rationale for the need to give a consistent interpretation of the term "human embryo" is the imperative of the Single European Market. The Single European Market, so it argues, may be impaired when the member states have different rules regarding the patentability of technologies derived from human embryonic stem cells. While the argument for harmonization might be convincing, the same argument could also be used as a rationale for a strict definition of the human embryo. ${ }^{6}$ Actually, a strict definition of the human embryo would be more in line with the explicit aim of Directive 98/44/E, namely, to enable a sustainable industrial and commercial development within the European Union (EU). Applying the Single European Market as an argument for a wide definition of "human embryo" and thus for a restriction of patentability seems a little odd to say the least.

\section{Deviation from well-}

\section{established principles}

\section{concerning moral}

\section{disagreement between}

\section{member states}

Another argument against the court's ruling is its deviation from well-established principles of its own case law as well as rulings by the European Court for Human Rights (ECHR). The ECJ has always argued that in those cases where a difference of values, cultures, or religions between the member states does not allow for a harmonized European legislation, the issue has to be judged by the different member states according to their own value systems. ${ }^{7}$ With little doubt, the sta-

\footnotetext{
${ }^{6}$ Also see: Spranger, Case Annotation, Case C-34/10, Oliver Brüstle v. Greenpeace e.V., in: Common Market Law Review 2012, 1197 (1202). ${ }^{7}$ See, for example, Rs. C-42/07.
}

tus of the human embryo is such an issue. This view is also supported by various rulings of the ECHR. ${ }^{8}$ Considering those rulings as well as the court's jurisdiction in other cases, ${ }^{9}$ the decision is quite astonishing. Neither does the court give any reasons why a deviation from this principle is necessary in the case of a patent law definition of the human embryo, nor have the member states moved any closer to a shared opinion regarding the moral and legal status of the human embryo.

\section{Inconsistency with the regulation's wording}

Article 6(2) explicitly sets out only the concretization of the general clause concluded in Article 1. In accordance with the worldwide practice of patent law, Article 6(1), however, determines, "Inventions shall be considered unpatentable where their commercial exploitation would be contrary to ordre public or morality." Thus, it is always and only the commercial utilization of an invention that is decisive for the analysis by patent law. Actions that have led to the invention or promoted it, and in this way ultimately concern the prior development of a technical instruction, ultimately do not play a role in the context of patent law. Therefore, not only does the evaluation of the Court of Justice offend against the wording of the Directive, which represents the outermost limit of every interpretation of a norm, but it also surpasses the understanding of what patent law can and should accomplish. ${ }^{10}$

\section{Tension with international trade law}

The definition of the human embryo, given by the ECJ European patent law, is

${ }^{8}$ Vo vs. Fance, 8th of July 2004 Application no. 53924/00, An. 84 f., also see S.H. vs. Austria, 3rd of November 2011, Application no. 57813/00, An. 94

${ }^{9}$ The principle is plainly laid down in an ECJ ruling on gambling, Rs. C-42/07, Rn. 58.

${ }^{10}$ Spranger, Case Annotation, Case C-34/10, Oliver Brüstle v. Greenpeace e.V., in: Common Market Law Review 2012, 1197 (1206). very broad indeed. It covers not only the human egg cell-from the moment of fertilization onward - but also the unfertilized ova into which a nucleus from a mature human cell has been transplanted and "any non-fertilized human ovum whose division and further development have been stimulated by parthenogenesis." The court clarifies that EU legislature intended to exclude any possibility of patentability where the respect for human dignity could be affected. It follows that the concept of "human embryo" according to the meaning of Article 6(2)(c) of the Directive must be understood in a wide sense. In light of this argument and regarding the emphasis on the capability "of commencing the process of development of a human being"-which is according to the court's opinion enough for an entity to be included in the concept of "human embryo"- the court's assessment has the potential for an even wider interpretation. It poses the question whether the so-called induced pluripotent stem cell embryos or even single induced pluripotent stem cells do also fall under this definition..$^{11}$ If this is the case, the ruling can have more far-reaching repercussions than the ECJ may have intended. At the same time, the wide definition clashes with Art. 27(1) TRIPs, which requires that "patents shall be available for any inventions, whether products or processes, in all fields of technology." Although Directive 98/44/EC explicitly acknowledges the obligations of the member states pursuant to international agreements, and in particular the TRIPs Agreement, the ECJ does not discuss this clash. Thus, a proceeding before the World Trade Organization is quite likely.

\section{Implications for other}

\section{areas of law}

One question following the decision concerns the impact of the findings of the

\footnotetext{
${ }^{11}$ See also Feldges, Annotation to the BrüstleCase, in; GRUR 2011, 1107 f. hin. Also: Spranger, Case Annotation, Case C-34/10, Oliver Brüstle v. Greenpeace e.V., in: Common Market Law Review 2012, 1197 (1203).
} 
ECJ on other areas than patent law, for instance, the field of funding. As one consequence of the decision, a move from European parliamentarians of different political factions who wish to stop funding research projects with human embryonic stem cells at the EU level can be recognized. They argue that it is legally inconsistent for the EU to fund research that cannot be patented within the EU. This might even legally void, so the argument goes, the upcoming framework program for research, Horizon 2020. This position was shared by the legal committee of the European Parliament in a corresponding request to change the framework program. However, these requests were met with strong objections in the legal-scientific community. Also at the political level, the industrial committee of the European Parliament has decided to maintain funding of research projects with human embryonic stem cells in the meantime and according to the previous rules. Within the scope of the prior 7th European Framework Program, it was agreed not to support research projects with European funding that included the destruction of human embryos. In addition, requests for funding could be approved only if they were in line with the regulations on stem cell research existing in the country of the applicant. The move to abandon funding of all research involving human embryonic stem cells and to widen the scope of the decision is primarily a political one. It is, nevertheless, backed up by a few legal scholars. ${ }^{12}$ The major rationale brought up in this context concerns the call of the unity of the EU legal order for a consistent definition of "human embryo," but this argument faces serious methodological challenges. First of all, the unity of the EU legal order just calls for a consistent inter-

${ }^{12}$ Starck, Christian, Annotation to the decision in: JZ 2012, $145 \mathrm{f}$.

\section{A Summation of the Findings from the ECJ}

- A uniform and very broad concept of "embryo" defined for patent law.

- Embryo defined as each human egg cell from the stage of fertilization onward.

- Every invention regarding a process that includes the prior destruction of embryos, or their use as source material, represents an industrial or commercial use.

- Is immaterial whether the process refers to human embryos.

- Using embryos for research purposes is an industrial or commercial use and leads to exclusion of patentability.

pretation of the same legal acts by all of the institutions and bodies of the EU. It does not call for a consistent definition of a term in different legal contexts. There is no methodological reason, for example, not to use one definition of "motor vehicle" in the context of European trade law and a totally different one in the context of European environmental law-there are indeed compelling reasons to do that. The same is true for the use of the term "human embryo" in differing legal fields such as patent law and regulations for research funding. Even if one might see the merit of using the same definitions in these vastly different fields, simply transferring the definition of "human embryo" from the ECJ's decision to other fields is methodologically unsound as it clearly is a case of a false conclusion a minori ad maius. The only way to establish such a far-reaching definition binding for all fields of European law is by a consensus of the member states to make it part of European primary law. There are, however, no indications that such a consensus might be reached in the foreseeable future. Indeed, the ECJ emphasizes that the scope of its definitions is limited to patent law alone. ${ }^{13}$

\section{CONCLUSION}

With its decision the ECJ excludes all inventions from patentability that include the prior destruction of embryos as well as their use as a source of material. They introduce a very wide definition of "human embryo" for European patent law, also covering unfertilized egg cells, which gain the potential to develop into complete organisms through artificial means. The rationale of the ECJ for giving such a broad definition as well as the ruling's consistency with international trade law has been severely questioned by large parts of the legal community. Bearing in mind the ECJ's own remarks on the scope of its findings and the legal methodology, one can be reasonably sure that the legal repercussions of the decisions will be limited to patent law. Any attempt to transfer this broad definition into other areas of European or national law would require a broad consensus of the member states on the status of the embryo, which is unlikely to be reached in the foreseeable future. What kind of impact the new rules on patenting will have on the future of European stem cell research remains to be seen.

\section{Author disclosure}

\section{statement}

No competing financial interests exist.

\footnotetext{
${ }^{13}$ Decision from November 3, 2011, Application no. 57813/00, An. 94.
} 